\title{
Characterization of acidic pumice and determination of its electrokinetic properties in water
}

\author{
Bahri Ersoy ${ }^{a, *}$, Ali Sariisik ${ }^{a}$, Sedef Dikmen ${ }^{b}$, Gencay Sariisik ${ }^{c}$ \\ a Afyon Kocatepe University, Faculty of Engineering, 03200 Afyonkarahisar, Turkey \\ ${ }^{\mathrm{b}}$ Anadolu University, Faculty of Science, 26470-Eskisehir, Turkey \\ c Afyon Kocatepe University, Vocational School of İscehisar, 03750 Iscehisar, Afyonkarahisar, Turkey
}

\section{A R T I C L E I N F O}

\section{Article history:}

Received 9 June 2009

Received in revised form 31 August 2009

Accepted 7 September 2009

Available online 15 September 2009

\section{Keywords:}

Pumice

Porosity

Material characterization

SEM

Zeta potential

\begin{abstract}
A B S T R A C T
In this study some characterization tests of acidic pumice were performed using various techniques such as Mercury Intrusion Porosimetry (MIP), Scanning Electron Microscope (SEM), X-Ray Diffraction (XRD), Thermal Analysis (DTA-TG), FTIR and its electrokinetic properties in water such as zeta potential (ZP), isoelectrical point (IEP), indifferent, specifically adsorbing and potential determining ions were determined. The results showed that (i) pore dimensions of the irregular or oval and fibrous cavities of the pumice varied between $0.05 \mu \mathrm{m}$ and $2 \mathrm{~mm}$ depending on its particle size and these cavities usually did not intersect each other; (ii) as the pumice particle size decreases, both total pore volume and total pore surface area significantly decrease as well; (iii) pumice maintained its thermal stability approximately up to $900^{\circ} \mathrm{C}$; (iv) pumice had a negative surface charge between $\mathrm{pH} 1.8$ and 11.4; and (v) $\mathrm{Cl}^{-}, \mathrm{Br}^{-} \mathrm{SO}_{4}^{2-}, \mathrm{Na}^{+}, \mathrm{Al}(\mathrm{OH})_{2}^{+}$ and $\mathrm{Ca}^{2+}$ ions were indifferent, $\mathrm{C}_{16} \mathrm{H}_{33}\left(\mathrm{CH}_{3}\right)_{3} \mathrm{~N}^{+}, \mathrm{Al}^{3+}$ and $\mathrm{Al}(\mathrm{OH})^{2+}$ cations were specifically adsorbing and, $\mathrm{H}^{+}$and $\mathrm{OH}^{-}$ions were potential determining ions for acidic pumice.
\end{abstract}

(c) 2009 Elsevier B.V. All rights reserved.

\section{Introduction}

Pumice is an amorphous, porous volcanic rock which is composed mainly of $\mathrm{SiO}_{2}$ and whose porous structure is formed by dissolved gases precipitated during the cooling as the lava hurtles through the air $[1,2]$. Having a reserve of nearly 3 billion $\mathrm{m}^{3}$, Turkey has important pumice deposits. Moreover, after Italy, Greece, China and Iran, respectively, Turkey is the fifth largest pumice producer in the world [3]. There are two kinds of pumice: acidic pumice and basic pumice. Acidic pumice is the most common pumice type both in Turkey and the world [1].

Pumice has high porosity and, as a result, low apparent density $\left(0.35-0.65 \mathrm{~g} / \mathrm{cm}^{3}\right)$ in aggregate form. It is therefore used in the construction industry, particularly in the production of light-weight brick and concrete elements that have thermal/acoustic insulation capabilities [1,4]. Many studies have been conducted to determine possible usage areas of pumice as well as the above-mentioned traditional usage area. In this scope, many researchers have studied the use of natural and/or modified pumice as an adsorbent for organic (i.e. phenol, textile dyes) and inorganic (various heavy metals and radioactive elements) water pollutants [5-9].

The term "electrokinetics" means the relative motions of charged species in an electric field. The field may be applied, or it may be created by the motion of a liquid or adjacent solid phase [10].

\footnotetext{
* Corresponding author. Tel.: +90 272 2281423; fax: +90 2722281422.

E-mail address: bersoy@aku.edu.tr (B. Ersoy).
}

However, the term "electrokinetic properties" carry a wider connotation including ZP the structure of electrical double layer (EDL), IEP, potential determining, indifferent and specifically adsorbing ions [11]. $\mathrm{ZP}$ is the electrical potential at the hydrodynamic plane of shear (or slipping plane) and is an intrinsic property of a mineral particle in a liquid [12]. That is, ZP is an important concept which is used to explain many physical, chemical and physico-chemical events such as adsorption, coagulation, stability, flotation and viscosity. Therefore, it is encountered in various fields such as environment -particularly in abatement of water pollution-, mining, pharmacy, ceramics and paint $[13,14]$. Accordingly, many studies in the literature have conducted ZP measurements of natural minerals under different conditions i.e. quartz, corundum, colemanite, calcite, clays, zeolites, coal to synthetic minerals i.e. silicon carbide, silicon, zirconia, carbon (fiber) [11]. Zeta potential measurements require high attention and sensitivity and, at the same time, the definition of the measurement conditions should be well identified because, as known from the literature, there can be very different ZP values and IEP's for the same mineral [15]. This variation is caused by direct effect through ZP values, and; other electrokinetic parameters due to various factors, which can be classified as: (i) pretreatments like washing, leaching, ultrasonic scrubbing, or de-sliming that may be used on a sample before measurement; (ii) impurities originating from the mine deposits or the mining process; (iii) variations in the test-conditions (premixture period, environment temperature, solid/liquid rate, purity of the water used; the type of instrument used for measurement and its application technique, and even the sensitivity of the person 
making the measurement and the hygiene conditions of the measuring location) [15-17].

Fuerstenau [18] studied the $\mathrm{ZP}$ of crystallized $\mathrm{SiO}_{2}$ (quartz) mineral (which has the same metal oxide compound as pumice) and reported that the IEP of quartz was pH 1.8. Huang and Fuerstenau [19] measured ZP of quartz suspension, on which an ultrasonic dispersion had been applied, and determined that its IEP was pH 2. Clark and Cooke [20] performed a detailed study on metal ion adsorption on quartz and pointed out $\mathrm{Na}^{+}$ions were indifferent, $\mathrm{Ca}^{2+}$ and $\mathrm{Mg}^{2+}$ ions were specifically adsorbed and $\mathrm{H}^{+}$and $\mathrm{OH}^{-}$are potential determining ions. Kosmulski [16] investigated the IEP of fused silica using six different zeta-meters and determined that several instruments produced negative ZPs across the entire $\mathrm{pH}$ range, while other instruments gave an IEP at pH 2-4. Similarly, Parks [15] reported varying IEPs for quartz (between pH 1.5 and 3.7) as well as other minerals, according to the pretreatments applied to the samples and experimental conditions. Even though many studies have been carried out on quartz, there is only one previous study on the ZP of pumice [21] in the literature. Tunç and Duman [21] examined the effect of different mono and multivalent electrolytes on the ZP of pumice from the Nevşehir region (Turkey). They reported that $\mathrm{Li}^{+}, \mathrm{Na}^{+}, \mathrm{K}^{+}, \mathrm{Cl}^{-}, \mathrm{ClO}_{4}^{-}, \mathrm{NO}_{3}^{-}, \mathrm{CO}_{3}^{2-}, \mathrm{SO}_{4}^{2-}$ and $\mathrm{PO}_{4}^{3-}$ are indifferent ions for pumice, and that the divalent cations $\left(\mathrm{Ca}^{2+}\right.$, $\mathrm{Mg}^{2+}$ etc.) are potential determining ions for pumice. The present authors suggest that, according to the results (ZP curves) obtained by Tunç and Duman [21], these cations are most likely indifferent or may be accepted as specifically adsorbing ions. In the present work, the electrokinetic properties (i.e. IEP, indifferent, specifically adsorbed and potential determining ions) of acidic pumice from the Tatvan region (Turkey) were investigated using some ZP measurements. The results were compared with those previously reported by Tunç and Duman [21]. In addition, Tatvan region has nearly half of the total Turkish pumice reserves, thus, the material characteristics of the acidic pumice collected from this region were determined in detail so as to promote this raw material in a better way.

\section{Experimental studies}

The pumice sample used in this study was collected from the Tatvan region of Turkey. The sizes of the sample as received were between 0.5 and $4 \mathrm{~cm} .500 \mathrm{~g}$ of sample was ground in a ball mill to reduce its size to $-125 \mu \mathrm{m}$. Without any further treatments such as washing, ultrasonic dispersing etc. the sample was subjected to ZP, BET, XRD, FTIR, XRF and Thermal Analysis (DTA-TG). Liquid pycnometer was used to measure the true density $\left(2.22 \mathrm{~g} / \mathrm{cm}^{3}\right)$ of the sample. The surface of the pumice in aggregate size was coated with paraffin and then its bulk density $\left(0.39 \mathrm{~g} / \mathrm{cm}^{3}\right)$ was measured according to Archimedes principle. The mineralogical and chemical analyses of the pumice sample were performed using XRD (Rigaku RINT 2200) and XRF (Rigaku ZSX Primus) techniques. FTIR analysis of the powder sample was carried out using Perkin Elmer Spectrum BX-2 having a standart mid-IR DTGS detector. FTIR spectra were recorded, in the range of $400-4000 \mathrm{~cm}^{-1}$ at a resolution of $4 \mathrm{~cm}^{-1}$ with $\mathrm{KBr}$ pellets technique. The $\mathrm{KBr}$ powder was prepared by mixing the pumice sample with $\mathrm{KBr}$ powder (around $1: 100$ ) and using a hydraulic press. In addition, thermal stability of the pumice was checked between 50 and $1200^{\circ} \mathrm{C}$ in alumina crucible in nitrogen atmosphere with the heating rate $5^{\circ} \mathrm{C} / \mathrm{min}$ (Setaram Setsys Evolution).

To see the inner pore structures (and pore morphology) the secondary electron images of fracture surfaces of pumice samples in aggregate size were obtained from a Scanning Electron Microscope (SEM Leo-1430 VP) equipped with an Energy Dispersive Spectrometry (EDS). Before SEM analysis, the fractured surfaces of the samples were coated with carbon. Moreover, to see its pore size distribution, total pore volume etc., the Mercury Intrusion Porosimetry analysis were performed on the pumice samples in different particle size fractions ( $<125 \mu \mathrm{m}, 1.173-2,2-4$ and $4-8 \mathrm{~mm}$ ) with Quantachrome
Poremaster 60 which generates pressure to 60,000 psia for pore size analysis from $440 \mu \mathrm{m}$ to $0.0036 \mu \mathrm{m}$ pore diameter. The mercury porosimeter is based upon the physical principle that a non-reactive, non-wetting liquid will not penetrate fine pores until sufficient pressure is applied to force its entry. The relationship between the applied pressure and the pore diameter into which mercury will intrude is given by the Washburn equation (Eq. (1)):

$D=(-4 \gamma \cos \theta) / P$

where $P$ is the applied pressure, $D$ is the pore diameter, $\gamma$ is the surface tension of the mercury ( $480 \mathrm{dyn} \mathrm{cm}^{-1}$ ) and $\theta$ is the contact angle between mercury and the pore wall, usually taken as $140^{\circ}$.

The ZP measurements of the pumice as a function of $\mathrm{pH}$ and that of salt concentration were carried out with a Malvern ZS90 Zetasizer using He-Ne red laser beam $(\lambda: 633 \mathrm{~nm})$ through M3-PALS (Mixed Mode Measurement Phage Analysis Light Scattering) technique. This instrument measures the $\mathrm{ZP}$ of the particle according to the electrophoresis method [11] with high sensitivity. Prior to the ZP measurements pumice powders were dried in an oven at $110^{\circ} \mathrm{C}$ for $2 \mathrm{~h}$ and stored in a plastic bag and throughout the measurements this sample was used. $2 \mathrm{~g}$ of pumice powders $(-125 \mu \mathrm{m})$ was dispersed into $50 \mathrm{ml}$ of a background electrolyte solution of $1 \mathrm{mM} \mathrm{NaCl}$ to ensure a constant ionic strength. The $\mathrm{pH}$ was adjusted using $1 \mathrm{M} \mathrm{KOH}$ or $1 \mathrm{M} \mathrm{HCl}$ and stirred for $1 \mathrm{~h}$ with a magnetic stirrer at room temperature $\left(25-26^{\circ} \mathrm{C}\right)$, afterwards, the suspension was centrifuged (Hettich Universal 32) for $10 \mathrm{~min}$ at $3500 \mathrm{rpm}$. Next, an aliquot of $0.75 \mathrm{ml}$ was taken from the supernatant solution and placed in electrophoresis cell, then an appropriate amount of sample from the pumice bed was transferred into the electrophoresis cell, afterwards, $\mathrm{ZP}$ was measured. Prior to the ZP measurements, stock solutions of $5 \times 10^{-2} \mathrm{M}$ of $\mathrm{NaCl}, \mathrm{Na}_{2} \mathrm{SO}_{4}, \mathrm{CaCl}_{2}, \mathrm{AlCl}_{3}$, and CTAB (cethyltrimethyl ammonium bromide, $\mathrm{C}_{16} \mathrm{H}_{33}\left(\mathrm{CH}_{3}\right)_{3} \mathrm{NBr}$ and that of $1.4 \times 10^{-2} \mathrm{M}$ of $\mathrm{CaSO}_{4} \cdot 2 \mathrm{H}_{2} \mathrm{O}$ were prepared with distilled water. All the organic and inorganic chemicals used in this study were purchased from Merck and were of analytical grade. Throughout the experimental work, distilled water was used and for $\mathrm{pH}$ adjustments Sartarous $\mathrm{pH}-$ Meter with glass electrode was used which has a sensitivity of \pm 0.01 .

\section{Results and discussion}

\subsection{Characterization}

According to the results of the XRD analysis of the pumice, there were two peaks: one at $23^{\circ}$ and the other at $28^{\circ}$ (Fig. 1). These peaks belonged to the mineral dachiardite $\left[(\mathrm{Ca}, \mathrm{Na}, \mathrm{K}, \mathrm{Mg})_{4},(\mathrm{Si}, \mathrm{Al})_{24} \mathrm{O}_{48}\right.$, $\left.13 \mathrm{H}_{2} \mathrm{O}\right)$ ], which is a kind of natural zeolite. In addition, the background line rose in $20^{\circ}-30^{\circ}$ range and formed a broad peak Since the 100 peak of the quartz is known to be at " $2 \theta=26.65^{\circ}$ ", this finding points out amorph quartz substance (i.e. pumice). A similar

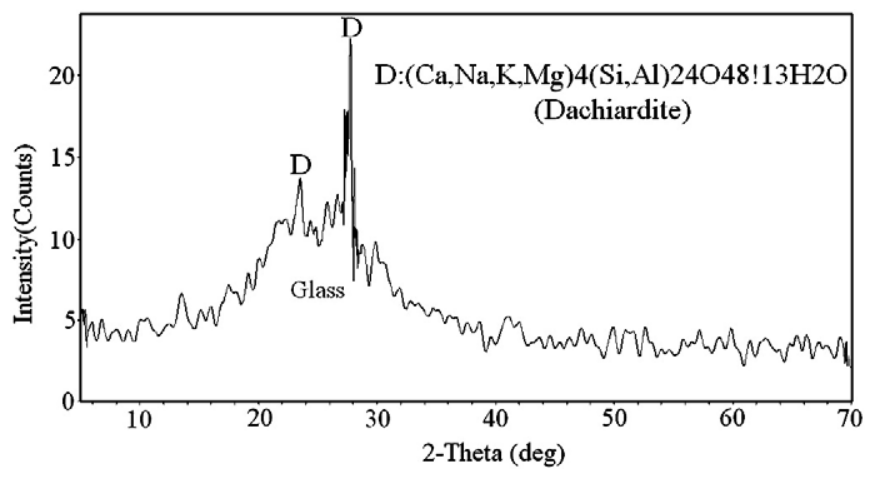

Fig. 1. XRD pattern of the pumice. 
situation is also recorded in sintered fly ash samples consisting of glassy phase [11] and also recorded for pumices obtained from different sources, such as the island of Lipali (Italy) $[22,23]$. This is also supported by the fact that no peak was recorded except for the peaks in the $2 \theta=20^{\circ}-30^{\circ}$ range. The chemical analyses of the pumice as weight \% were $\mathrm{SiO}_{2} 70.21, \mathrm{Al}_{2} \mathrm{O}_{3}$ 13.63, $\mathrm{K}_{2} \mathrm{O} 5.12, \mathrm{Na}_{2} \mathrm{O} 2.20, \mathrm{CaO} 2.11$, $\mathrm{Fe}_{2} \mathrm{O}_{3}$ 1.72, $\mathrm{MgO} 0.60, \mathrm{MnO} 0.26, \mathrm{TiO}_{2} 0.16, \mathrm{SO}_{3} 0.09, \mathrm{P}_{2} \mathrm{O}_{5} 0.08$, and LOI 3.82. As seen from the values, the two most important components of the sample were $\mathrm{SiO}_{2}$ and $\mathrm{Al}_{2} \mathrm{O}_{3}$. It can be concluded that the higher the silica percentage, the purer the pumice will be. Moreover, high iron oxide content not only darkens the color of the pumice but also increases its density. And high density is an undesirable characteristic in terms of insulation performance. The peaks at 400 and $800 \mathrm{~cm}^{-1}$ in the FTIR spectrum of the pumice (Fig. 2) may have resulted from the $\mathrm{Si}-\mathrm{O}$ bending strength vibrations of the amorphous quartz which constituted the structure while the strong peak around $1100 \mathrm{~cm}^{-1}$ may have resulted from Si-O stretching vibrations. The other important peak was detected around $3400 \mathrm{~cm}^{-1}$. This peak pointed out the $\mathrm{OH}$ stretching vibrations of the water (moisture) which was adsorbed by the sample from the outside environment [24]. The literature suggests that the water adsorbed from the outside environment produces a deformation vibration peak around $1640 \mathrm{~cm}^{-1}$ [24]. Considerable differences were detected between the FTIR spectrums of the present study and of the study conducted with the acidic pumice collected from Nevşehir region of Turkey [25]. For example, the important peak recorded in the present study around $1100 \mathrm{~cm}^{-1}$ was not recorded in the spectrum of the Nevşehir sample. This may have resulted from the differences in the physical and chemical characteristics of the samples used in these two studies: the pumice used in the present study was under the $125 \mu \mathrm{m}$ while the one used in that study was under $63 \mu \mathrm{m}$. The literature indicates that different grain sizes may result in differences in the peak intensities of the FTIR spectra [24]. Moreover, there were some impurities in the sample used in the present study; however, no mineralogical data was available in the prior study. Therefore, variations in mineral and chemical contents may have played a role in the differing results obtained in these two studies.

TG and DTA curves derived from the thermal analysis under nitrogen atmosphere are shown in Fig. 3. Pumice loses about 3.5\% of its mass between 100 and $400^{\circ} \mathrm{C}$, due to the removal of moisture within powder pumice and volatile organic impurities, which may be present in small proportions. LOI value (via chemical analysis) and mass loss (via TG curve) are similar, thus this supports the comment given above. On the other hand, the endothermic peak of the DTA curve between the ranges of 25 and $100^{\circ} \mathrm{C}$ can be a sign for that case; however, as the temperature range of this peak is not correlated with the TG curve, a clear explanation cannot be made for this situation. DTA curves of quartz reported in the literature indicate an endothermic peak around $573^{\circ} \mathrm{C}[24,26]$, resulting from the phase conversion of quartz from $\alpha$ - to $\beta$-quartz. Pumice has an amorphous

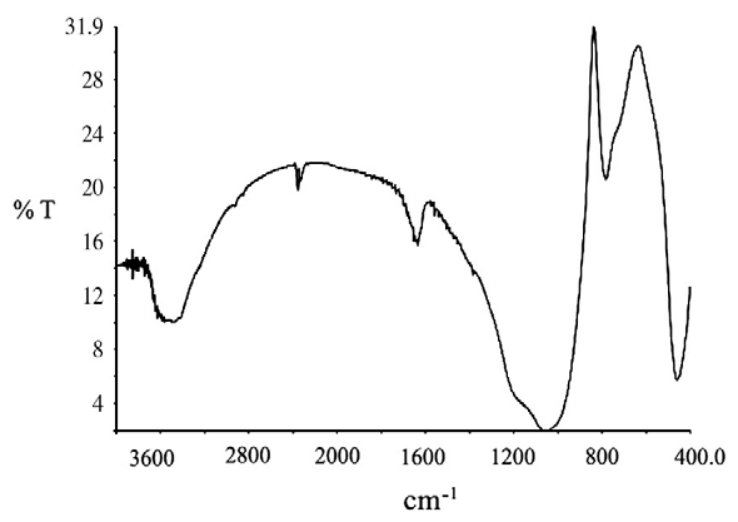

Fig. 2. FTIR spectrum of the pumice.

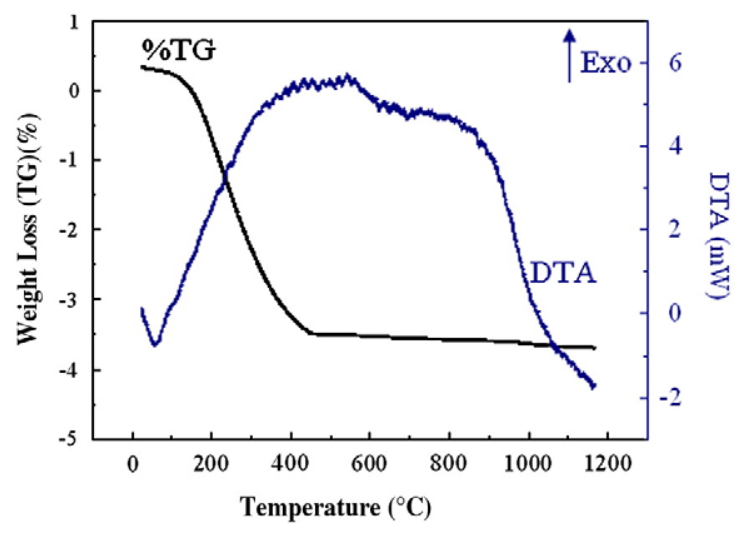

Fig. 3. DTA-TG curves of the pumice.

structure, rather than a crystalline structure, so it is normal not to see an endothermic peak at the defined temperature. According to DTA curve, the endothermic peak beginning at $900{ }^{\circ} \mathrm{C}$ indicates the structural change in pumice i.e. softening and beginning of melting. Thermal analysis of pumice from the Nevşehir region reported that pumice becomes soft at $850{ }^{\circ} \mathrm{C}$ and melts completely around $1200{ }^{\circ} \mathrm{C}$ [1]. As a result, acidic pumice can retain its thermal stability until $900{ }^{\circ} \mathrm{C}$.

Spaces, holes, channels and cracks within a mineral structure are generally defined as pores. Micropores are defined as having a width smaller than 2 nanometers $(\mathrm{nm})(20 \AA$, angstrom), mesopores are between $2 \mathrm{~nm}$ and $50 \mathrm{~nm}$, and macropores are larger than $50 \mathrm{~nm}$ [27]. Considering the characterization of materials, porosity (and control of porosity) in terms of pore volume, size and their distribution is very important in many industries, products and processes, including building materials, ceramics and sintered materials, catalysts, electrodes, surgical implants, pharmaceuticals, and membranes [28,29]. Mercury intrusion results are commonly presented in the form of cumulative volume intruded per mass of specimen as a function of pore diameter. So, Fig. 4 indicates the cumulative pore size distribution measured with MIP of pumice samples of size fractions $<125 \mu \mathrm{m}, 1.173-2 \mathrm{~mm}$ and $4-8 \mathrm{~mm}$. However, it should be noted that the MIP tool used in the porosity measurements of this study, as expressed in the Experimental studies section, can measure pore diameters from a maximum of $440 \mu \mathrm{m}$ to a minimum of $0.0036 \mu \mathrm{m}$; therefore, pores larger than $440 \mu \mathrm{m}$ are determined from a normal photograph image of pumice aggregate. In terms of Fig. 4, within 1.173-2 and 4-8 $\mathrm{mm}$ particle fractions, pore size distribution curves of pumices are similar, but that of pumice in powder form (below $125 \mu \mathrm{m}$ ) differs from the other two. To express this more clearly, curves representing the larger particle groups are stepped, while curves for the smaller particle sizes are not. This finding suggests that when the particle sizes of pumice decrease, its pore morphology changes from heterogeneous to homogeneous structure. This heterogeneous structure can clearly be seen in the normal images derived from pumice aggregate and SEM images (Figs. 5 and 6). The term heterogeneous refers to the different size pore groups within the material. When pore sizes are taken into account, it can be seen that the pore size of the pumice aggregate varies across a wide range, with the smallest pore diameter being $0.05 \mu \mathrm{m}$, in contrast, the smallest pore diameter of the pumice in powder form is approximately $0.5 \mu \mathrm{m}$. According to the SEM images of the pumice aggregate, the minimum pore diameter is about $1 \mu \mathrm{m}$, a significant difference is seen considering the porosimeter result. This may be attributed the heterogeneous structure of pumice in aggregate size. As a result, the minimum pore diameter of pumice in aggregate size can be accepted as $0.05 \mu \mathrm{m}$. In the literature, a study using Greek pumice found that the MIP and pore size distributions of pumice belonged to two different groups [2] $1.18-2.36$ and $2.36-4.75 \mathrm{~mm}$ and it was 


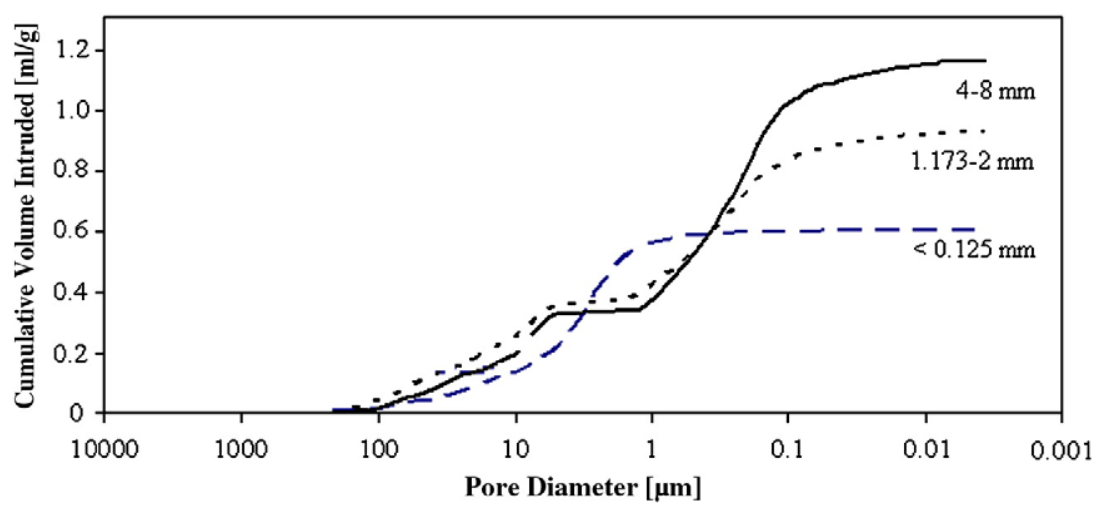

Fig. 4. Cumulative pore size distribution of the pumice samples of different size fractions plotted against pore diameter.

determined that both pumice samples showed homogeneous dimension pore size distribution, in contrast with the result of the present study, and the minimum pore diameters were found to be approximately $0.001 \mu \mathrm{m}$. So, in terms of both the homogeneity of pores and pore sizes, the pumice samples from the Tatvan region (Turkey) and Yali Island (Greece) show crucial differences. The reason for this difference is probably the differing geological formation conditions. Total mercury intruded volume (or total pore volume) $(\mathrm{ml} / \mathrm{g})$ and total pore surface area $\left(\mathrm{m}^{2} / \mathrm{g}\right)$ values measured by MIP according to the particle size fractions of the pumice are given in Table 1. From Table 1, it can be seen that when the particle size decreases, both total pore volume and total pore surface area decrease significantly. This decrease is proportionally greater for total pore surface area. For both parameters (total pore volume and total pore surface area), the highest values are derived for the pumice in 4$8 \mathrm{~mm}$ particle fraction, $1.1620 \mathrm{ml} / \mathrm{g}$-pumice and $10.9219 \mathrm{~m}^{2} / \mathrm{g}$ pumice respectively. The results indicate that Tatvan pumice, both in aggregate and powder size, was comprised mostly of macro-sized pores.

Photograph and SEM images detailing the micro-structure (that is, inner pore structure) of the acidic pumice are shown in Figs. 5 and 6, respectively. EDS (Energy Dispersive Spectrometer) analysis was made on a point which was randomly selected from the SEM photo (Fig. 6b, indicated by white arrow). According to the normal photo (Fig. 5) and SEM images (Fig. 6a and b), the pumice sample has irregular or oval shaped and fibrous cavities (or pores), in addition, it may be said that these pores are either in closed or in open forms. The pore diameter of these cavities varied between $0.5 \mu \mathrm{m}$ and $2 \mathrm{~mm}$ and these cavities generally did not intersect each other. It is reported that [2] the connectivity of the pore structure of pumice may range from completely closed to completely open. The greater the extent to which a mineral structure has a closed form and pores which do not

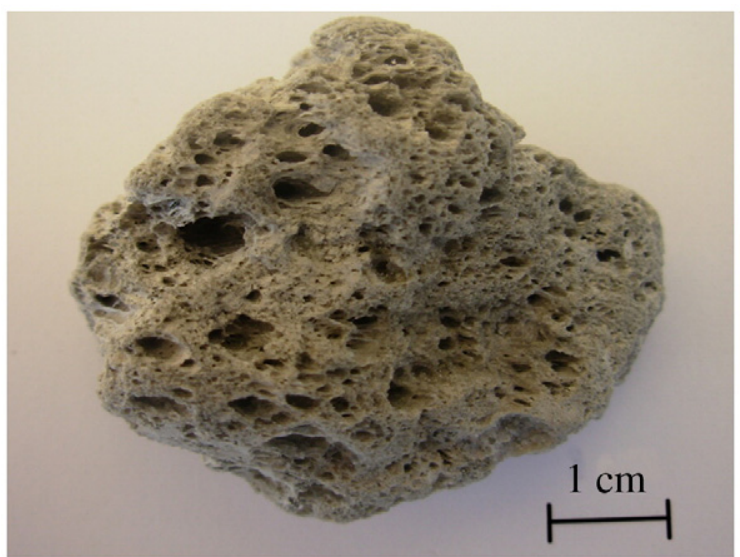

Fig. 5. Photograph of the pumice aggregate (as-received). intersect, the greater its thermal and acoustic insulation performance $[1,28]$. Moreover, the glassy phase structure of the pumice can be seen in Fig. 6b. According to the element analysis of the area marked in Fig. $6 \mathrm{~b}$ the peaks were recorded -from biggest to the smallest- in $\mathrm{Si}$, $\mathrm{Al}, \mathrm{K}$ and $\mathrm{Fe}$.

\subsection{ZP of the pumice versus $\mathrm{pH}$}

ZP variation of the pumice on the basis of $\mathrm{pH}$ is shown in Fig. 7. The results indicate that the pumice did not reach its IEP between $\mathrm{pH} 2$ and 11.4 and the lowest $\mathrm{ZP}(-0.97 \mathrm{mV})$ was obtained around $\mathrm{pH} 2$. As the $\mathrm{pH}$ increased, $\mathrm{ZP}$ rapidly increased in the negative direction and reached $-35 \mathrm{mV}$ at $\mathrm{pH} 7.5$ and $-38 \mathrm{mV}$ at about $\mathrm{pH} 11$. Even though we could not measure a positive $\mathrm{ZP}$ value of pumice between $\mathrm{pH} 1.8$ and 11.2, Tunç and Duman [21] measured the positive ZP of pumice from a different pumice deposit within Turkey (Nevşehir region). Accordingly, they also determined the IEP of pumice as $\mathrm{pH} 2.7$ in water. This may be attributed to the differing chemical and mineralogical characteristics of the pumice samples. In addition, they applied ultrasonic scrubbing pretreatment to their pumice sample, which has been shown in the literature to affect the ZP value of minerals [30]. In addition, there are many studies on quartz, which has a crystalline structure. The curve obtained for the pumice was similar to that for the quartz, with the exception that ZP started to decrease at high $\mathrm{pH}$ values in the pumice sample. Also, the IEP of the quartz is reported as $\mathrm{pH} 2-3[10,12]$. The decrease in $\mathrm{ZP}$, associated with the increase in $\mathrm{pH}$ between $\mathrm{pH} 2$ and 11 , may be explained by (i) adsorption -via coulombic interaction- of the $\mathrm{OH}^{-}$ions present in the suspension to the positive charge centers such as $\equiv \mathrm{Si}^{+}$and $\equiv \mathrm{Si}-\mathrm{OH}_{2}^{+}$, which are present on the particle surface of pumice and which come out during the grinding process as a result of the breaking of bonds, or; (ii) dissociation (deprotonation) of $\equiv \mathrm{Si}-\mathrm{OH}$ groups at the particle surface. All these reactions show that the $\mathrm{H}^{+}$and $\mathrm{OH}^{-}$ions are the PDI for pumice, that is, they establish the surface charge of the pumice. The literature indicates that this is a common phenomenon for various metal oxides or metal hydroxides [11,14,24].

\subsection{Effect of different electrolytes on ZP}

The effects of the various metal salts (inorganic electrolytes) with mono-, di- and trivalent and organic electrolyte (CTAB, which is a kind of cationic surfactant) on the $\mathrm{ZP}$ of the pumice were examined. ZP variations according to each electrolyte concentration are presented in Fig. 8. As clearly seen from Fig. 8, the only two electrolytes that could change the negative surface charge of the pumice into a positive surface charge were $\mathrm{AlCl}_{3}$ and $\mathrm{C}_{16} \mathrm{H}_{33}\left(\mathrm{CH}_{3}\right)_{3} \mathrm{NBr}$ (CTAB). This result means that free $\mathrm{Al}^{3+}$ with trivalent and also its hydrated form $\mathrm{Al}(\mathrm{OH})^{2+}$ with divalent metallic ions, and $\mathrm{C}_{16} \mathrm{H}_{33}\left(\mathrm{CH}_{3}\right)_{3} \mathrm{~N}^{+}\left(\mathrm{CTA}^{+}\right)$with monovalent organic cation can be adsorbed in the inner Helmholtz plane (IHP) in the Stern layer in the EDL of the pumice and thus they can be accepted as 

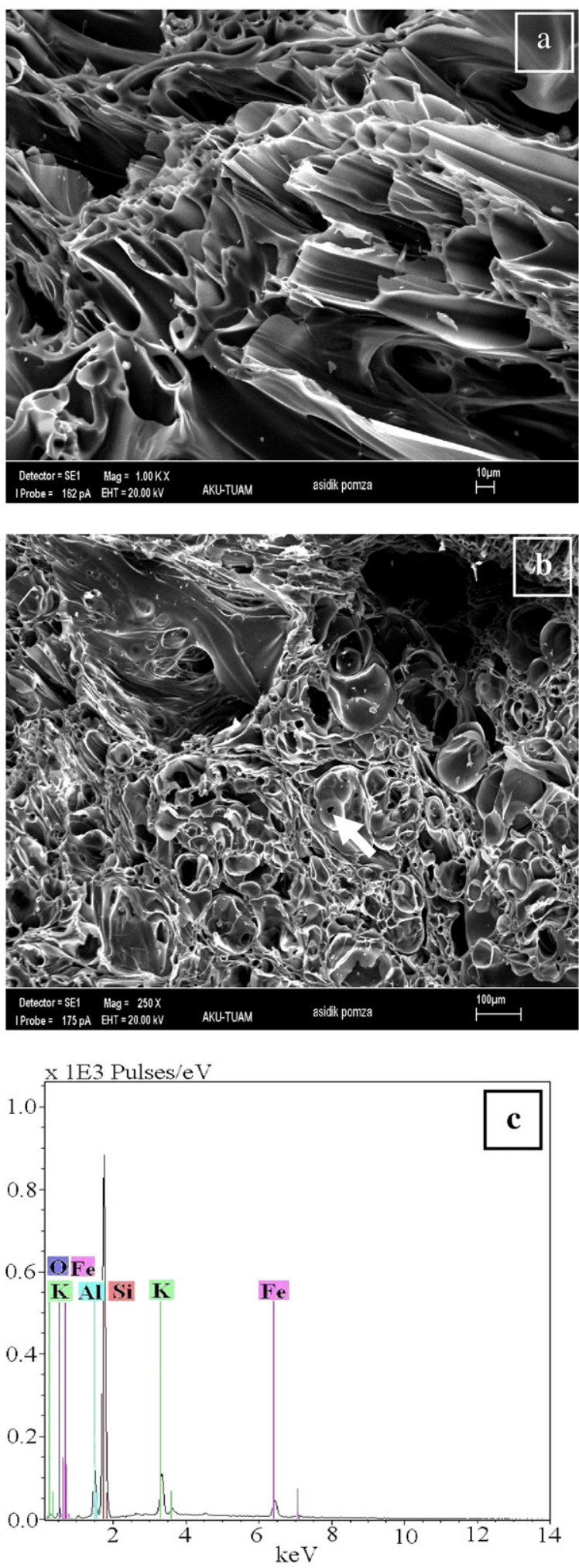

Fig. 6. SEM images of the pumice sample (a) scaled up by $\times 1000$ times, (b) scaled up by $\times 250$ times and (c) EDS point analysis (the point marked with an arrow in the SEM photo at the bottom).

specifically adsorbing ions for pumice. Depending on the electrolyte concentration (from $10^{-6}$ to $10^{-2} \mathrm{M}$ ), the suspension $\mathrm{pH}$ varied between pHs 6.0 and 4.1 for $\mathrm{AlCl}_{3}, 6.9$ and 5.8 for $\mathrm{CaCl}_{2} / \mathrm{CaSO}_{4}, 7.5$ and 6.0 for $\mathrm{NaCl} / \mathrm{Na}_{2} \mathrm{SO}_{4}$, and 7.2 and 6.6 for CTAB. As is known from the literature [31-33] metallic ions hydrolyze in aqueous environment. Adsorption of such ions onto solids and phenomena dependent on
Table 1

Total intruded volume (or total pore volume) $\left(\mathrm{ml} / \mathrm{g}\right.$ ) and total pore surface area $\left(\mathrm{m}^{2} / \mathrm{g}\right)$ values given by MIP depending on the particle size fractions of the pumice.

\begin{tabular}{llll}
\hline & \multicolumn{2}{l}{ Size fractions } & \\
\cline { 2 - 4 } & $4-8 \mathrm{~mm}$ & $1.173-2.0 \mathrm{~mm}$ & $<0.125 \mathrm{~mm}$ \\
\hline $\begin{array}{c}\text { Total mercury intruded volume } \\
\text { (or total pore volume) }(\mathrm{ml} / \mathrm{g})\end{array}$ & 1.1620 & 0.9304 & 0.6036 \\
Total pore surface area $\left(\mathrm{m}^{2} / \mathrm{g}\right)$ & 10.9219 & 9.8773 & 1.1535 \\
\hline
\end{tabular}

adsorption is related to hydrolysis and the formation of hydrolysis products. In general, unhydrolyzed $\mathrm{Me}^{3+}$ (i.e. $\mathrm{Al}^{3+}, \mathrm{Fe}^{3+}$ etc.) or $\mathrm{Me}^{2+}$ (i.e. $\mathrm{Ca}^{2+}, \mathrm{Mg}^{2+}$, etc.) species predominate in acidic solutions, while $\mathrm{MeOH}^{2+}, \mathrm{Me}(\mathrm{OH})_{2}^{+}, \mathrm{Me}(\mathrm{OH})^{+}, \mathrm{Me}(\mathrm{OH})_{3}$ and $\mathrm{Me}(\mathrm{OH})_{4}^{-}$for $\mathrm{Me}^{3+}$, and $\mathrm{Me}(\mathrm{OH})^{+}$and $\mathrm{Me}(\mathrm{OH})_{2}$ for $\mathrm{Me}^{2+}$ appear when the $\mathrm{pH}$ is made more alkaline (see Fig 9a and b). In the model proposed by James and Healy [34], a non-hydrolyzed ion is strongly attracted to a negative surface but it is so strongly solvated that it cannot approach the surface. Reduction of the charge through hydrolysis ( to $\mathrm{MeOH}^{2+}, \mathrm{Me}(\mathrm{OH})_{2}^{+}$, etc.) reduces the attraction to the solid but also reduces the salvation energy which falls off more rapidly with hydrolysis. Coulombic interactions between nonhydrolyzed strongly solvated ions and negatively charged solid surfaces are not sufficient to cause adsorption of such ions, the adsorption becomes possible when solvation of these ions (through hydrolysis) is reduced. In this case, according to Figs. 8 and 9a, it is assumed that either $\mathrm{Al}^{3+}$ or $\mathrm{Al}(\mathrm{OH})^{2+}$ can adsorb specifically onto pumice, consequently they convert the surface charge of pumice from negative to positive passing a zero $\mathrm{ZP}$, which was obtained at $1.2 \times 10^{-4} \mathrm{M}$ of $\mathrm{AlCl}_{3}$. This is because the suspension $\mathrm{pH}$ varied between $\mathrm{pH} 4.5$ and 4.0 in accordance with the $\mathrm{AlCl}_{3}$ concentrations range of $10^{-4}-10^{-3} \mathrm{M}$. Fig. 9a indicates that, at around $\mathrm{pH} 4$, the dominant soluble species are $\mathrm{Al}^{3+}$ and $\mathrm{Al}(\mathrm{OH})^{2+}$. Tunç and Duman [21] determined the zero ZP of the Nevşehir Pumice in the presence of $\mathrm{AlCl}_{3}$ at $2 \times 10^{-4} \mathrm{M}$, which is very close to the concentration value obtained from our study. On the other hand, Ersoy and Çelik [35] examined the $\mathrm{Al}(\mathrm{NO})_{3}$ effect on the $\mathrm{ZP}$ of clinotilolite (zeolite) mineral and determined that the free $\mathrm{Al}^{3+}$ ions are PD ions for clinoptilolite, similar to the results of the present study. Likewise, organic ions with monovalent, $\mathrm{CTA}^{+}$, are able to reverse the negative charge of the pumice by means of its specific adsorption onto pumice. Similar results have been obtained for different minerals such as quartz [36], clinoptilolite [37], and bentonite [38]. Specifically adsorbed ions possess special affinity for the solid surface through coulombic and noncoulombic forces. These noncoulombic forces may be chemical in nature, i.e., involving some degree of covalent bonding with surface atoms or be more physical, e.g., van der Walls forces between the ion and the surface or between the hydrocarbon chains of surfactant ions adsorbed [12]. Zero ZP of pumice was obtained about at $7 \times 10^{-5} \mathrm{M} \mathrm{CTAB}$ concentration.

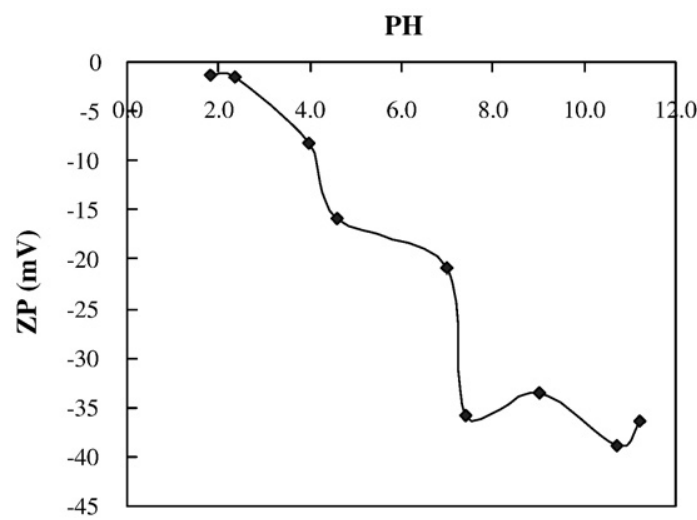

Fig. 7. Zeta potential variation of pumice as a function of $\mathrm{pH}$ at constant ionic strength $(I=1 \mathrm{mM} \mathrm{NaCl})$ at $25 \pm 1{ }^{\circ} \mathrm{C}$. 


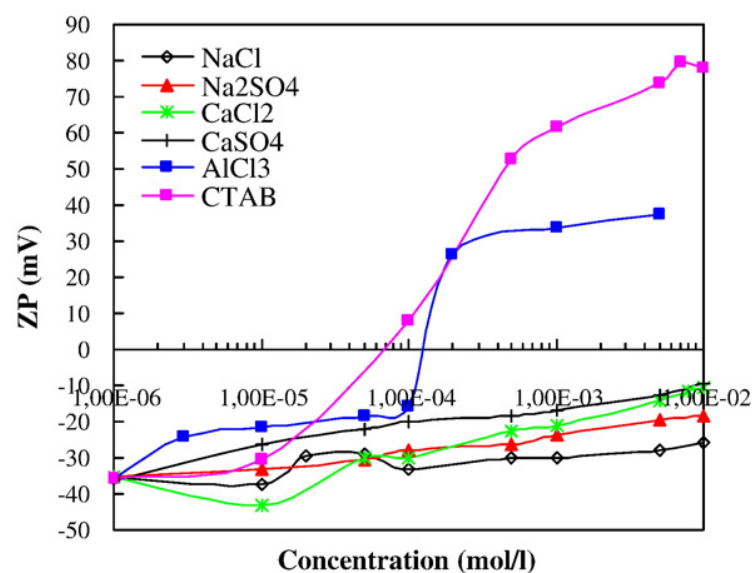

Fig. 8. Zeta potential variation of pumice as a function of the concentration of different electrolytes at $25 \pm 1{ }^{\circ} \mathrm{C}$ at natural pHs (note: depending on the electrolyte concentration (from $10^{-6}$ to $10^{-2} \mathrm{M}$ ) the suspension $\mathrm{pH}$ varied between $\mathrm{pHs} 6.0$ and 4.1 for $\mathrm{AlCL}_{3}, 6.9$ and 5.8 for $\mathrm{CaCl}_{2}$ and $\mathrm{CaSO}_{4}, 7.5$ and 6.0 for $\mathrm{NaCl}$ and $\mathrm{Na}_{2} \mathrm{SO}_{4}$, and 7.2 and 6.6 for $\mathrm{CTAB}$ )

ZP decreased from $-36.1 \mathrm{mV}$ to $-10.4 \mathrm{mV}$ in $10^{-2} \mathrm{M} \mathrm{CaCl}_{2}$ concentration. The $\mathrm{ZP}$ decrease recorded in the presence of $\mathrm{CaSO}_{4}$ was higher than the $\mathrm{ZP}$ decrease recorded in the presence of $\mathrm{CaCl}_{2}$ and $\mathrm{ZP}$ was found to decrease to $-8.4 \mathrm{mV}$ at $10^{-2} \mathrm{M}$ concentration which

$\mathbf{a}$ Total $[\mathrm{A} 1(\mathrm{III})]=10^{-4} \mathrm{M}$

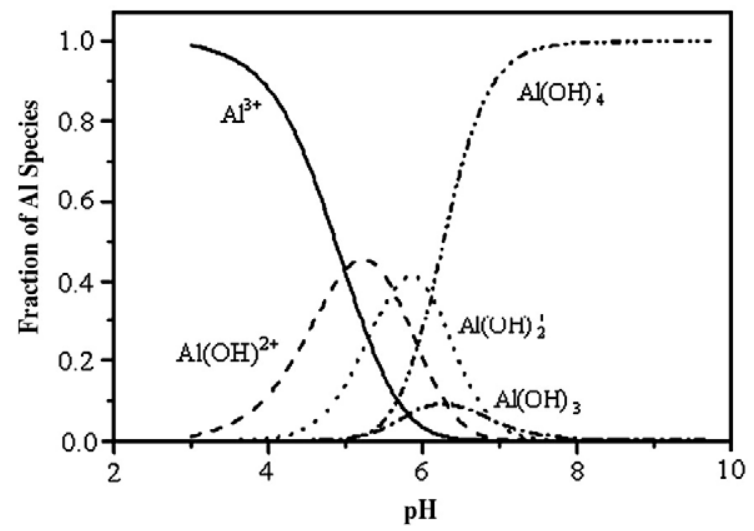

b

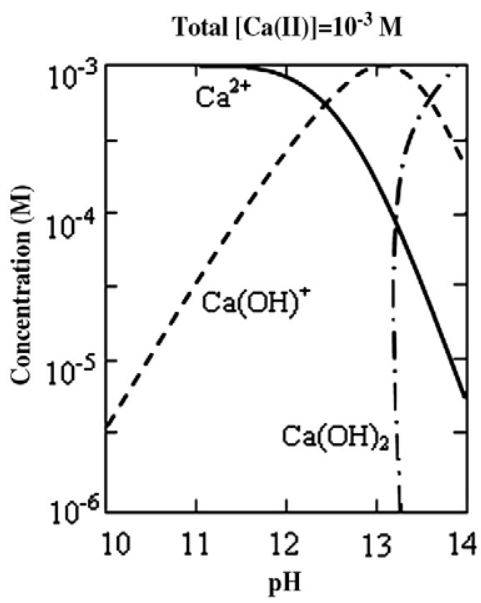

Fig. 9. Mole fractions of monomeric hydrolysis products of aluminum [32] (a) and concentrations of monomeric hydrolysis products of calcium species and (b) in equilibrium with the amorphous hydroxides as function of $\mathrm{pH}$ for $10^{-4} \mathrm{M}$ total $\mathrm{Al}^{3+}$ and $10^{-3} \mathrm{M}$ total $\mathrm{Ca}^{2+}[18]$. may be attributed to the differences in the dissociation constants of these electrolytes. As seen from the Fig. 9b, the $\mathrm{Ca}^{2+}$ ions should be mostly in unhydrolyzed $\mathrm{Ca}^{2+}$ forms below $\mathrm{pH} 11$ but above this $\mathrm{pH}$ $\mathrm{CaOH}^{+}$ions become predominant in solution. As mentioned previously, the $\mathrm{pH}$ of pumice suspension in the presence of Ca salts varied between $\mathrm{pH} 7.5$ and 6.0, therefore, for both Ca salts the predominant ionic form is $\mathrm{Ca}^{2+}$. At result, according to the general trend of the curves of $\mathrm{CaCl}_{2}$ and $\mathrm{CaSO}_{4}$, there are no dramatic increases in the curves but steady increases are seen; in addition, a charge reversal is not apparent. Consequently, the $\mathrm{Ca}^{2+}$ ions may be accepted as indifferent ions for pumice. Hunter [12] reported that specifically adsorbed ions can be recognized by their ability to reverse the sign of zeta potential (ZP), whereas indifferent ions can only reduce ZP asymptotically to zero. In contrast, Tunç and Duman [21] claimed that the divalent cations (i.e. $\mathrm{Ca}^{2+}, \mathrm{Mg}^{2+}$ ) are PD ions for pumice. The present authors suggest that, according to the obtained results (ZP curves) by [21], these cations are most likely indifferent or may be accepted as specifically adsorbing ions. On the other hand, Clark and Cooke [20] performed a detailed study on metal ion adsorption on quartz and pointed out that $\mathrm{Na}^{+}$is an indifferent ion, whereas $\mathrm{Ca}^{2+}$ and $\mathrm{Mg}^{2+}$ are specifically adsorbed ions. However, no zeta potential curve is seen in their study [20] - that is, they have not made any ZP measurement in the presence of these metal ions. Therefore, it is not possible to make a comparison of ZP curves. When examined, the ZP curves of the metal salts with monovalent, $\mathrm{Na}_{2} \mathrm{SO}_{4}$ were found to be relatively more effective than $\mathrm{NaCl}$ in reducing $\mathrm{ZP}$. ZP values obtained at $10^{-2} \mathrm{M} \mathrm{NaCl}$ and $\mathrm{Na}_{2} \mathrm{SO}_{4}$ concentrations were -26.0 and $-18.2 \mathrm{mV}$, respectively. It seen that some electrolytes $(\mathrm{NaCl}$ and $\mathrm{Na}_{2} \mathrm{SO}_{4}$ ) are, for practical purposes, indifferent; their addition shows an insignificant change on the $\mathrm{ZP}$. As a result, both curves indicate that $\mathrm{Cl}^{-}, \mathrm{Br}^{-} \mathrm{SO}_{4}^{2-}$ and $\mathrm{Na}^{+}$were indifferent ions for pumice, which is in agreement with the results obtained by Tunç and Duman [21], in which a different pumice sample and similar metal salts were used.

\section{Conclusions}

The acidic pumice collected from the Tatvan region of Turkey had irregular or oval shaped and fibrous cavities (porosity). Pore diameter of these cavities varied between $0.05 \mu \mathrm{m}$ and $2 \mathrm{~mm}$ depending on its particle size and they, in general, did not intersect each other. Moreover, it was found that, when the particle size of pumice decreases (especially from aggregate size to powder size $(<125 \mu \mathrm{m})$, there is a significant decrease in both total pore volume and total pore surface area and this decrease is most significant for the total surface area. On the other hand, the pumice maintained its thermal stability up to approximately $900^{\circ} \mathrm{C}$. The pumice had a negative charge in the $1.8-11.4 \mathrm{pH}$ range and the lowest $\mathrm{ZP}$ value was recorded as $-1.4 \mathrm{mV}$ when the $\mathrm{pH}$ value was approximately 2 . The negative surface charge could only be turned into a positive charge in the presence of $\mathrm{AlCl}_{3}$ and CTAB. According to their impacts on the reduction of zeta potential, electrolytes were ordered as follows: "CTAB $>\mathrm{AlCl}_{3}>\mathrm{CaSO}_{4}>\mathrm{CaCl}_{2}>\mathrm{Na}_{2} \mathrm{SO}_{4}>\mathrm{NaCl}$ ". This indicates that the interaction between the negatively charged pumice powders and cationic species enhances with increase in valance number of metal ions. However, when metal powder was compared with organic electrolyte, although the organic electrolyte (CTAB) has monovalent cation $(\mathrm{CTA}+)$, it is more active in reducing the zeta potential of pumice than the $\mathrm{AlCl}_{3}$ with trivalent $\mathrm{Al}^{3+}$ and makes the zeta potential of pumice zero at a lower concentration. In addition, $\mathrm{OH}^{-}$and $\mathrm{H}^{+}$ions were found to be the potential determining ions for the acidic pumice. Also $\mathrm{Al}^{3+}, \mathrm{Al}(\mathrm{OH})^{2+}$ and $\mathrm{C}_{16} \mathrm{H}_{33}\left(\mathrm{CH}_{3}\right)_{3} \mathrm{~N}^{+}$were specifically adsorbing ions while the di and monovalent cations and anions $\mathrm{Cl}^{-}, \mathrm{Br}^{-} \mathrm{SO}_{4}^{2-}$, $\mathrm{Na}^{+}, \mathrm{Al}(\mathrm{OH})_{2}^{+}$and $\mathrm{Ca}^{2+}$ were indifferent ions for the pumice. As a result, acidic pumice might be used, especially in neutral and basic mediums, as an adsorbent material for positively charged species or contaminants in waters/wastewaters. 


\section{Acknowledgements}

This study was carried out within the scope of Project Code No. 07. MUH.07 supported by the Scientific Research Commission of Afyon Kocatepe University (BAPK).

\section{References}

[1] L. Gündüz, A. Sariisik, B. Tozaçan, M. Davraz, I. Uğur, O. Çankıran, Pumice Technology (in Turkish), SDU Matbaası, Isparta, 1998.

[2] P. Lura, D.P. Bentz, D.A. Lange, K. Kovler, A. Bentor, Pumice aggregates for internal water curing, International RILEM Symposium 22-24 (2004) 137-151.

[3] W.P. Bolen, Pumice and pumicite, Minerals Yearbook, vol. 130, U.S. Geological Survey, Virginia, USA, 2008

[4] L. Cavaleri, N. Miraglia, M. Papia, Pumice concrete for structural wall panels, Engineering Structures 25 (2003) 115-125.

[5] N.K. Pazarlığlu, R.O. Ürek, F. Ergun, Biodecolourization of Direct Blue 15 by immobilized Phanerochaete chrysosporium, Process Biochemistry 40 (2005) 1923-1929.

[6] F. Akbal, Adsorption of basic dyes from aqueous solution onto pumice powder, Journal of Colloid and Interface Science 286 (2005) 455-458.

[7] M. Yavuz, F. Gode, E. Pehlivan, S. Ozmert, Y.C. Sharma, An economic removal of $\mathrm{Cu}^{2+}$ and $\mathrm{Cr}^{3+}$ on the new adsorbents: pumice and polyacrylonitrile/pumice composite, Chemical Engineering Journal 137 (2007) 453-461.

[8] F. Akbal, Sorption of phenol and 4-chlorophenol onto pumice treated with cationic surfactant, Journal of Environmental Management 74 (2005) 239-244.

[9] M. Kitis, S.S. Kaplan, E. Karakaya, N.O. Yiğit, G. Civelekoğlu, Adsorption of natural organic matter from waters by iron coated pumice, Chemosphere 66 (2007) $130-138$.

[10] V.A. Hackley, C.F. Ferraris, The Use of Nomenclature in Dispersion Science and Technology, U.S. Government Printing Office, Washington, 2001.

[11] M.Y.A. Mollah, S. Promreuk, R. Schennach, D.L. Cocke, R. Güler, Crystobalite formation from thermal treatment of Texas lignite fly ash, Fuel 78 (1999) 1277-1282.

[12] R.J. Hunter, Zeta Potential in Colloid Science, Academic Press Inc., San Diego, 1981.

[13] J.N. Israelachvili, Intermolecular and Surface Forcessecond edition, Academic Press Inc, London, 1992.

[14] M.S. Çelik, B. Ersoy, Mineral nanoparticles: electrokinetics, in: J.A. Schwarz, C.I. Contescu, K. Putyera (Eds.), Encyclopedia of Nanoscience and Nanotechnology, Marcel-Dekker Inc, New York, 2004, pp. 1991-2005.

[15] G.A. Parks, The isoelectric points of solid oxides, solid hydroxides, and aqueous hydroxo complex systems, Chemical Reviews 65 (1965) 177-198.

[16] M. Kosmulski, A literature survey of the differences between the reported isoelectric points and their discussion, Colloids and Surfaces A: Physicochem Engineering Aspects 222 (2003) 113-118.

[17] R.D. Kulkarni, P. Somasundaran, Effect of pretreatment on the electrokinetic properties of quartz, International Journal of Mineral Processing 4 (1977) 89-98.
[18] M.C. Fuerstenau, Oxide and silicate flotation, in: K.A. Matıs (Ed.), Flotation Science and Technology, Marcel Dekker Inc, New York, 1995, p. 558.

[19] P. Huang, D.W. Fuerstenau, The effect of the adsorption of lead and cadmium ions on the interfacial behavior of quartz and talc, Colloids and Surfaces A: Physicochem Engineering Aspects 177 (2001) 147-156.

[20] S.W. Clark, S.R.B. Cooke, Adsorption of calcium, magnesium and sodium ion by quartz, Society of Mining Engineers (AIME) 241 (1968) 334-341.

[21] S. Tunc, O. Duman, Effects of electrolytes on the electrokinetic properties of pumice suspensions, Journal of Dispersion Science and Technology 30 (2009) 548-555.

[22] I. Arrigo, P. Catalfamo, L. Cavallari, S. Di Pasquale, Use of zeolitized pumice waste as a water softening agent, Journal of Hazardous Materials 147 (2007) 513-517.

[23] X.Y. Chuan, M. Hirano, M. Inagaki, Preparation and photocatalytic performance of anatase-mounted natural porous silica, pumice, by hydrolysis under hydrothermal conditions, Colloids and Surfaces B:Environmental 51 (2004) 255-260.

[24] R. Grim, Clay Mineralogy, McGraw-Hill Book Company, New York, 1968, p. 596.

[25] A. Gök, F. Göde, B.E. Türkaslan, Synthesis and characterization of polyaniline/ pumice (Pan/Pmc) composite, Materials Science and Engineering B 133 (2006) 20-25.

[26] M. Karakaya, Properties of Clay Minerals and Identification Methods (in Turkish), Bizim Büro Press, Ankara, 2006.

[27] Y. Sarıkaya, Physical Chemistry (in Turkish), Özkan Matbaacılık San, Ankara, 1993.

[28] W.D. Kingery, Introduction to Ceramics, John Wiley\&Sons, New York, 1960.

[29] J.S. Reed, Principles of Ceramics Processing (Second Edition), John Wiley \& Sons Inc, New York, 1994

[30] R.D. Kulkarni, P. Somasundaran, Effect of pretreatment on the electrokinetic properties of quartz, International Journal of Mineral Processing 4 (1977) 89-98.

[31] J. Gregory, Fundamental of flocculation, Critical Reviews in Environmental Controls 19 (1989) 185-230.

[32] J. Duan, J. Gregory, Coagulation by hydrolysing metal salts, Advances in Colloid and Interface Science 100-102 (2003) 475-502.

[33] J.S. Laskowski, Activation in flotation circuits, Proceedings of Xth Int. Mineral Processing Symposium, Çeşme-Turkey, 2004, pp. 377-391.

[34] R.O. James, T.W. Healy, Adsorption of hydrolyzable metal ions at the oxide-water interface. Part III. Journal of Colloid and Interface Science 40 (1972) 65-81.

[35] B. Ersoy, M.S. Celik, Electrokinetic properties of clinoptilolite with mono and multivalent electrolytes, Microporous and Mesoporous Materials 55 (2002) 305-312.

[36] D.W. Fuerstenau, T.W. Healy, P. Somasundaran, The role of hydrocarbon chain of alkyl collectors in flotation, Transactions, vol. 229, AIME, 1964, pp. 321-325.

[37] B. Ersoy, M.S. Çelik, Effect of hydrocarbon chain length on adsorption of cationic surfactants onto clinoptilolite, Clays and Clay Minerals 2 (2003) 173-181.

[38] S. Isçi, E. Günister, A Alemdar, Ö.I. Ece, N. Güngör, The influence of DTABr surfactant on the electrokinetic and rheological properties of soda-activated bentonite dispersions, Materials Letters 62 (2007) 81-84. 